\title{
LESS IS MORE: LOW-COST IN VITRO PROPAGATION OF AN ENDANGERED ITALIAN ORCHID
}

\author{
Jacopo Calevo', Miriam Bazzicalupo² \\ ${ }^{1}$ University of Turin, Italy \\ ${ }^{2}$ University of Genoa, Italy \\ *e-mail: jacopo.calevo@gmail.com
}

Received: 06.04.2020. Revised: 23.06.2020. Accepted: 11.07.2020.

\begin{abstract}
Orchids are among the most widely distributed plants but also the most threatened by biotic and abiotic factors. Their interactions with specific symbiotic fungi during germination in natural environments make their propagation challenging for conservation biologists. In this study, in the framework of the European conservation project LIFEorchids, the germination protocol for the endangered Mediterranean species Orchis patens was optimised, and the effect of controlled constant temperature in growth chambers with fluctuations of temperature occurring in natural environments was compared. Seed viability was also evaluated by using a double-staining technique. Minimum, maximum and average daily temperatures were recorded for six months, from July to December, and germination percentages, as well as developmental stages of seeds, were annotated, for both conditions, every month. Even if germination was obtained under both conditions, the effect of temperature fluctuations was evident, by increasing the germination percentage of seeds from about $10 \%$ under controlled conditions to $59 \%$. The latter result was almost comparable with seed viability data, indicating a strong impact of temperature fluctuations in breaking seed dormancy. Our results are a confirmation that temperature oscillations play a more important role than the average temperature in seed germination and suggest avoiding a constant temperature to optimise germination protocols for European orchid species.
\end{abstract}

Key words: asymbiotic germination, ex situ conservation, Orchidaceae, Orchis patens, temperature, viability

\section{Introduction}

Among the different plant families, Orchidaceae is one of the most distributed, showing great adaptability to different habitats and environmental conditions (Swarts \& Dixon, 2017). Orchids are known for their strict relationships with specialised pollinators and mycorrhizal fungi (Darwin, 1862; Leake, 1994; Girlanda et al., 2006; Dixon, 2009). They are at risk of extinction by biotic and abiotic factors affecting their habitats (Swarts \& Dixon, 2009), including weed invasion, grazing, biological resources use, altered hydrology, climate change and irregular urbanisation (Swarts \& Dixon, 2009; Wraith \& Pickering, 2018). Regarding the rich circum-Mediterranean orchid flora, clearing of habitats, over-collection and habitat degradation have resulted in many taxa becoming rare and endangered (Kretzschmar et al., 2007). For these reasons, in situ and ex situ efforts have lately increased in conservation programmes which included more and more often in vitro propagation (Fay, 1994; Pierce \& Belotti, 2011; Calevo et al., 2018).

Orchis patens Desf. is a threatened Mediterranean orchid with a wide disjunct distribution. According to Euro+Med (2006), it includes O. patens subsp. patens (Fig. 1), occurring in Algeria, Tuni- sia and Italy (limited to Liguria, from Savona to $\mathrm{La}$ Spezia), and $O$. patens subsp. canariensis (Lindl.) Asch. \& Graebn., an endemic of the Canary Islands (Spain). The taxonomy is currently under debate and focus of an investigation. The species inhabits both the edge of cities, rural areas (e.g. Italy) and natural environments, in full to mid-sun.

Orchis patens is threatened by residential development and inappropriate agricultural practices (e.g. mowing during flowering), leading to a reduction of suitable habitats. Wild boars (Sus scrofa Linnaeus, 1758) cause large-scale damage to the plants by excavating their tubers (Calevo et al., 2014). In addition, due to its beauty, the species is the target of illegal collection. For these reasons $O$. patens is protected in Liguria with a regional law (LR n. 28, 10.07.2009) and is included in the European IUCN Red List (Bilz et al., 2011) and in the Italian Red List (Orsenigo et al., 2016) as Endangered.

Orchis patens is also one the two flagship species of a five-years' LIFE project (LIFEorchids LIFE17NAT/IT/000596), co-funded by the European Union, which aims to the conservation of selected orchid species and their habitats in North-Western Italy (Calevo et al., 2018). 


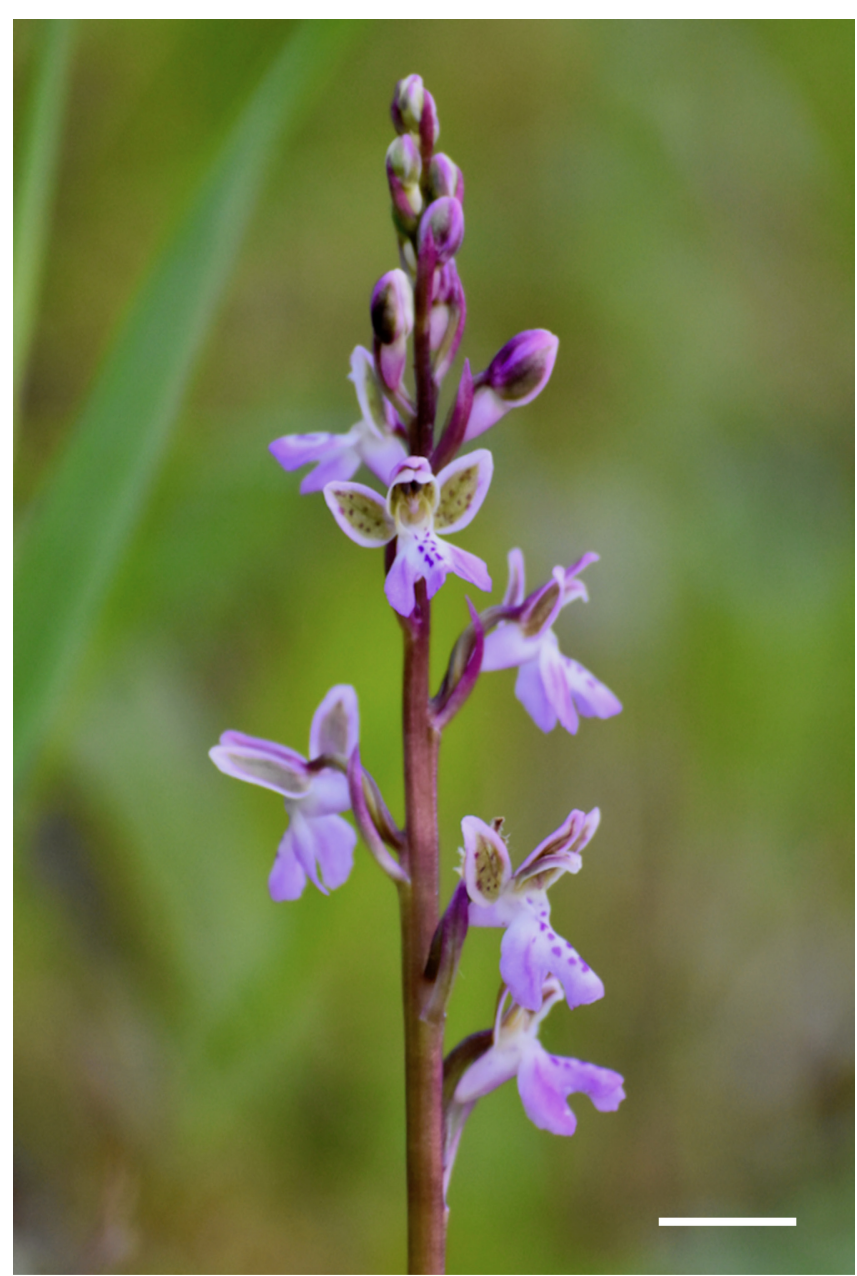

Fig. 1. Inflorescence of Orchis patens subsp. patens, Liguria, Italy, 2019 (scale bar $=1 \mathrm{~cm})$.

Despite its rarity and threatening status, this species' ecology and biology is largely understudied. Calevo et al. (2017a) described $O$. patens seed micromorphology and attempted the first in vitro asymbiotic germination that yielded very low germination percentages and very slow germination under controlled conditions possibly due to the thickness of the seed coat (Calevo et al., 2017b). The latter authors, indeed, suggested that a cold stratification of at least two weeks could have helped in breaking seed dormancy.

The importance of temperature in promoting and inhibiting seed germination is well documented and responses are highly variable among species (Johnson \& Kane, 2012). Cold stratification (Baskin \& Baskin, 2001; Han \& Long, 2010) and fluctuating temperatures (Baskin \& Baskin, 2001, 2003) have also been shown to break dormancy and/or promote germination.

This study aimed to optimise the germination protocol and to compare the germination ability of $O$. patens seeds under controlled conditions (in the laboratory using growth chambers) with seeds kept under the natural environmental oscillations of temperatures.

\section{Material and Methods \\ Hand pollination and seed collection \\ Orchis patens (Fig. 1) was fertilised in May 2019} by hand cross-pollination of plants from San Rocco and Breccanecca (Province of Genoa, Liguria, Italy). Ten capsules were collected from each locality 55 days after pollination and stored in a paper envelope at $4^{\circ} \mathrm{C}$ until use.

\section{Seed viability}

Three aliquots taken from the seed group of each population were used to assess seed viability. The material was sterilised and scarified in a solution of $1 \%$ sodium hypochlorite with $0.1 \%$ of Tween 20 (Calevo et al., 2017c) for $20 \mathrm{~min}$. After scarification, seeds were washed for $10 \mathrm{~min}$. for three times, using sterile water.

Following the double staining approach proposed by Magrini et al. (2019a), scarified seeds were soaked in a solution of $1 \%$ TTC red chloride (2,3,5-triphenyltetrazolium chloride, $\mathrm{pH}$ 7) and kept in the dark at $30^{\circ} \mathrm{C}$ for $24 \mathrm{~h}$. After one day the solution was removed and the seeds were washed three times in distilled water for $3 \mathrm{~min}$. each, followed by centrifugation at $6000 \mathrm{rpm}$ for $1 \mathrm{~min}$. between rinses. Seeds were then stained with a second dye in a solution of $0.4 \%$ trypan blue (Sigma) for 2 min., and then rinsed twice in distilled water followed by centrifugation at $6000 \mathrm{rpm}$ for $1 \mathrm{~min}$. between rinses (Magrini et al., 2019b). The presence of blue-stained testas, an indicator of seed permeability, was checked using a Leica M50 stereomicroscope.

\section{Germination tests}

For germination test, seeds were first scarified and surface sterilised as previously performed in the seed viability experiment. Seeds were then sown in Petri dishes directly on solid Malmgren Orchid Medium M551 (Phytotechnology), following the protocol indicated by Ercole et al. (2015), with the pH adjusted at 5.8 with $1 \mathrm{M} \mathrm{KOH}$. Sixteen Petri dishes, each one containing about 100 seeds, were divided into two groups: eight Petri dishes were kept in dark under controlled condition of temperature, $21 \pm 2^{\circ} \mathrm{C}$, while the other eight ones were put in a clean polystyrene box (in dark) and placed in the Botanic Garden of Turin (Italy) under natural temperature condition. Minimum, maximum and average daily temperatures were recorded for six months, from July to December (Fig. 2), and germination percentages were annotated, for both conditions, every month. Seed developmental stages were also documented according to Swarts \& Dixon (2017) to which a sixth stage was added (Table 1). 


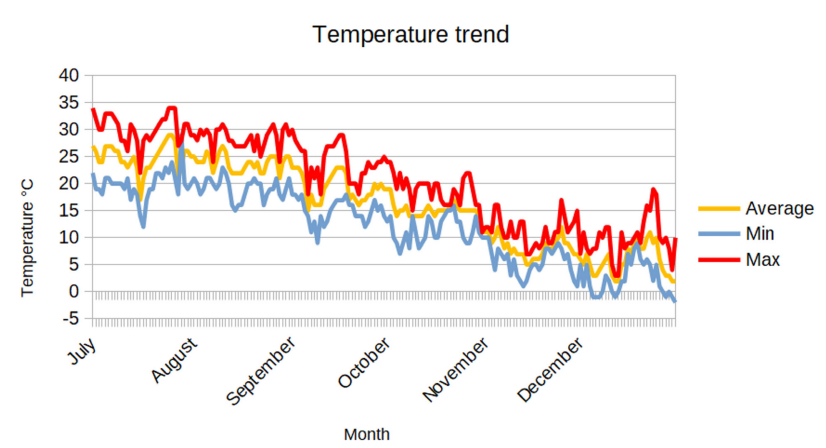

Fig. 2. Minimum (min), maximum (max) and average daily temperature trend from July to December.

Table 1. Description of developmental stages (implemented from Swarts \& Dixon, 2017)

\begin{tabular}{|l|l|}
\hline Stage & Description \\
\hline Stage 1 & Unimbibed seed with intact testa \\
\hline Stage 2 & Imbibed seed - splitting of testa and swollen embryo \\
\hline Stage $3^{1}$ & Rupture of testa and development of first rhizoids \\
\hline Stage $4^{1}$ & Enlargement of protocorm and formation of protomeristem \\
\hline Stage $5^{1,2}$ & Further enlargement and development of first green leaf \\
\hline Stage $6^{1,2}$ & Emission of second green leaf \\
\hline
\end{tabular}

\section{Data analysis}

A t-test with a cut-off significance at $\mathrm{p} \leq 0.05$ was used to statistically compare seed viability percentages and daily temperature fluctuations data and to analyse germination results.

\section{Results and Discussion}

Seeds collected from San Rocco yielded a viability of $82.1 \pm 4.4 \%$ (excluding not permeable seeds for which no blue testa was observed). No differences in viability were observed in seeds collected from Breccanecca which yielded a viability percentage of $78.7 \pm 2.9 \%$ (excluding not permeable seeds). About $12 \%$ and $15 \%$ of total seeds were not permeable for San Rocco and Breccanecca, respectively. Germination occurred both in controlled condition and in Petri dishes under environmental temperatures (Fig. 3, Table 2).

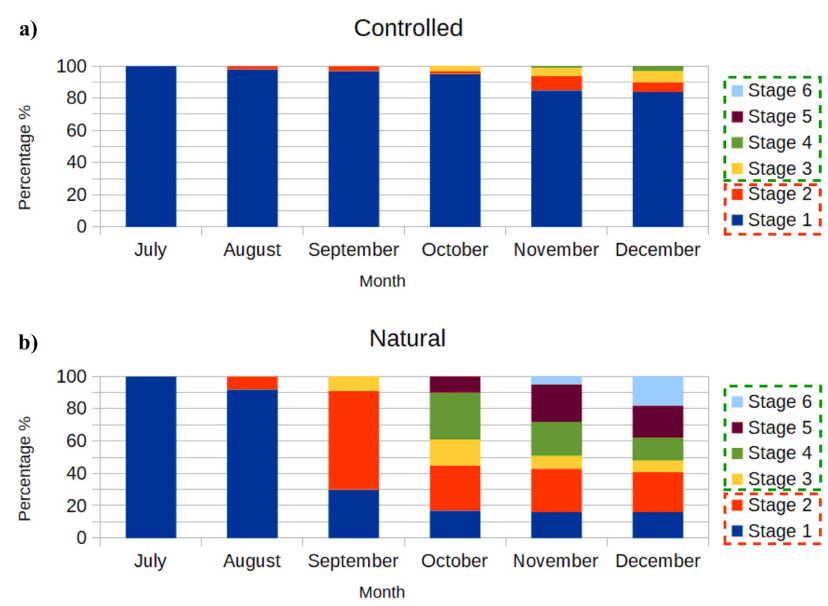

Fig. 3. Monthly average germination percentage of different developmental stages under both a) controlled and b) natural conditions. Seeds at stages 1 and 2 were not germinated, while at stages 3, 4, 5 and 6 are considered as germinated (implemented from Swarts \& Dixon, 2017).

After six months, the final germination (including stages $3,4,5$ and 6 ) was $59.3 \pm 2.9 \%$ under natural conditions and $10.2 \pm 1.8 \%$ under controlled conditions (Table 2). Germination percentage yielded under natural conditions is in line with the viability percentage, considering that not germinated seeds may include not only those seeds that were not viable $(17-22 \%)$ but also the seeds that were not permeable (12-15\%).

Calevo et al. (2017b) obtained $6.30 \pm 1.12 \%$ of germination only 12 months after sowing, while here a similar percentage was obtained by six months. This may be due to the use of a different germination medium. In that study, indeed, a modification of Malmgren medium (MALM) was used that lacked some micronutrients and organic compounds that are instead present in the M551 medium used in this research (Malmgren, 1996). The comparison with germination of other Orchis spp., such as Orchis mascula (L.) L. (Valletta et al., 2008), would be inappropriate since $O$. patens is the only polyploid species in the genus exhibiting, therefore, very different germination times and capability. Indeed, previous studies reported that polyploidy may affect the timing of meiosis (Leitch \& Fay (2008) and references therein).

Table 2. Germination of seeds by months under natural and controlled conditions

\begin{tabular}{|l|c|c|}
\hline \multicolumn{1}{|c|}{ Month } & Natural conditions & Controlled conditions \\
\hline July & 0 & 0 \\
\hline August & 0 & 0 \\
\hline September & $9.2 \pm 1.7^{\mathrm{a}}$ & $0^{\mathrm{b}}$ \\
\hline October & $55.1 \pm 2.7^{\mathrm{a}}$ & $3.2 \pm 0.9^{\mathrm{b}}$ \\
\hline November & $56.9 \pm 3.1^{\mathrm{a}}$ & $6.4 \pm 1.2^{\mathrm{b}}$ \\
\hline December & $59.3 \pm 2.9^{\mathrm{a}}$ & $10.2 \pm 1.8^{\mathrm{b}}$ \\
\hline
\end{tabular}

Note: Data were statistically analysed by $\mathrm{t}$-test with a cut-off significance at $\mathrm{p} \leq 0.05$. 
However, even if sometimes a cold stratification of seeds before sowing is enough to break seed dormancy (Sharma et al., 2003), and even if Calevo et al. (2017b) also suggested this treatment for $O$. patens, it did not enhance germination in previous attempts. Only the treatment under natural oscillations of temperatures here reported showed significant differences in germination percentage (Table 2).

After two months, in late August, no germination was observed, considering the development of the first rhizoids as an indicator of germination (stage 3). In late September, stage 3 was only observed in Petri dishes under natural conditions and the latter seeds developed into stage 4 in October. Seeds that were kept under controlled conditions, instead, germinated (stage 3 ) in October and later developed to stage 4 in November and December.

Stage 5 , the first photosynthetic stage, was only observed in Petri dishes under natural conditions starting from October (Fig. 3), when the average daily temperatures were constantly below $20^{\circ} \mathrm{C}$ (Fig. 2). Stage 6, the emission of the second leaf, was also observed, under natural conditions, starting from November and further increased in December (Fig. 3).

The main germinations of seeds under natural conditions occurred in the cold months of October and November, when the monthly temperature mean were of $15^{\circ} \mathrm{C}$ and $8^{\circ} \mathrm{C}$, respectively (Table 3 ). But it is important to notice that the bulk of seeds $(9.2 \pm 1.7 \%)$ started to break their dormancy in September, much earlier compared to seeds under controlled conditions, even if the mean monthly temperature was around $20^{\circ} \mathrm{C}$.

It is known that for some species, seed dormancy can be overcome by exposing seeds to cold, moist conditions through a treatment known as stratification (Rost et al., 2006; Poff et al., 2016), such as Platanthera praeclara Sheviak \& M.L. Bowles (Sharma et al., 2003) or Cypripedium calceolus L. (Pierce \& Belotti, 2011). However, we must point out that, in the past, constant cold stratification $\left(8^{\circ} \mathrm{C}\right)$ was not enough for enhancing germination of $O$. patens. Even if in the months, in which seeds started to germinate, the average temperature was almost comparable with the temperature of growth chambers, the daily mean temperature fluctuation was higher when compared to the following months. We may hypothesise, therefore, that daily fluctuations of temperatures, more than the monthly mean temperatures, play a pivotal role in breaking the seed dormancy of $O$. patens. The daily fluctuations of the summer months, indeed, were significantly higher than in October and November when the majority of germination occurred at significantly lower mean temperatures. Therefore, summer temperature fluctuations may have an important role in breaking the dormancy while the lower temperatures of autumn months are essential for germination and development.

However, it is important to remind that our study was performed in the framework of an asymbiotic germination experiment, and that different mechanisms may act in natural environments where the interaction with appropriate symbiotic fungi and competition with seed pathogens take place (Calevo et al., 2020).

We have also noticed that seedlings exposed to fluctuating temperatures developed tubers after eight months, while seedlings obtained under controlled conditions of growth chambers usually take two years to develop them or need the addition of hormones to the medium to stimulate tuber formation (Stewart \& Kane, 2006).

Table 3. Minimum (min), maximum (max), monthly average temperatures $\left({ }^{\circ} \mathrm{C}\right)$ and overall monthly mean of daily fluctuations of temperatures $\left({ }^{\circ} \mathrm{C}\right)$

\begin{tabular}{|l|c|c|c|c|}
\hline \multicolumn{1}{|c|}{ Month } & Min & Max & Monthly mean \pm SD & Overall monthly mean of daily fluctuations \pm SD \\
\hline July & 12 & 34 & $24.93 \pm 2.53^{\circ}$ & $10.37 \pm 2.98^{\mathrm{a}}$ \\
\hline August & 15 & 31 & $23.87 \pm 1.50^{\circ}$ & $9.26 \pm 2.31^{\mathrm{a}}$ \\
\hline September & 9 & 30 & $19.37 \pm 2.62^{\mathrm{b}}$ & $9.17 \pm 3.12^{\mathrm{a}}$ \\
\hline October & 7 & 24 & $15.10 \pm 1.47^{\mathrm{c}}$ & $7.52 \pm 4.32^{\mathrm{b}}$ \\
\hline November & 1 & 17 & $8.23 \pm 1.89^{\mathrm{d}}$ & $5.77 \pm 3.63^{\mathrm{c}}$ \\
\hline December & -2 & 19 & $5.74 \pm 2.74^{\mathrm{d}}$ & $7.48 \pm 3.84^{\mathrm{bc}}$ \\
\hline
\end{tabular}

Note: Statistical comparisons of the latter were analysed by a t-test with a cut-off significance at $\mathrm{p} \leq 0.05$. Designation: SD - standard deviation. 


\section{Conclusions}

In conclusion, we compared the germination ability of Orchis patens seeds under controlled and natural conditions. Our results emphasise the importance of temperature oscillations for stimulating seeds germinability by breaking their dormancy. This suggests that growth chambers are not always required for ex situ conservation of temperate orchids and that putting Petri dishes under natural temperature condition can make us save space and money but more importantly enhance seed germination and seedlings development to produce more seedlings that can be acclimatised in shorter time. In the future, it will be interesting to see, if the same feedbacks will be obtained in non-axenic conditions while interacting with symbiotic and non-symbiotic micro-organisms.

\section{References}

Baskin C.C., Baskin J.M. 2001. Seeds: Ecology, Biogeography, and Evolution of Dormancy and Germination. San Diego: Academic Press. 666 p.

Baskin C.C., Baskin J.M. 2003. When breaking seed dormancy is a problem: try a move-along experiment. Native Plants Journal 4(1): 17-21. DOI: 10.3368/npj.4.1.17

Bilz M., Kell S.P., Maxted N., Lansdown R.V. 2011. European Red List of Vascular Plants. Luxembourg: Publications Office of the European Union. 144 p.

Calevo J., Massa G., Maglio M. 2014. Elenco delle Orchidaceae del Parco Regionale di Portofino. GIROS Notizie 57: 35-39.

Calevo J., Giovannini A., Cornara L., Peccenini S., Monroy F. 2017a. Orchispatens Desf.: seedmorphology ofanendangered Mediterranean orchid. Plant Biosystems 151(5): 770-774. DOI: 10.1080/11263504.2017.1297335

Calevo J., Monroy F., Peccenini S., Cornara L., Giovannini A. 2017b. First time in vitro asymbiotic germination of Orchis patens Desf.: a preliminary study on an endangered Mediterranean orchid. GIROS Orchidee Spontanee d'Europa 60(1): 94-104.

Calevo J., Giovannini A., Cornara L., Peccenini S. 2017c. Asymbiotic seed germination of hand-pollinated terrestrial orchids. Acta Horticolturae 1155: 415-418. DOI: 10.17660/ActaHortic.2017.1155.61

Calevo J., Voyron S., Portigliatti A., Monroy F., Giovannini A., Cornara L., Giordani P., Girani A., Zocco D., Cristaldi L., Palazzolo P., Colombo S., Marzorati M., Moravec J., Perotto S., Girlanda M. 2018. Orchids for LIFE: the LIFE17NAT/IT/000596 project for the conservation of orchids and their habitat. GIROS Orchidee Spontanee d'Europa 61(2): 277-288.

Calevo J., Voyron S., Ercole E., Girlanda M. 2020. Is the Distribution of Two Rare Orchis Sister Species Limited by Their Main Mycobiont? Diversity 12(7): 262. DOI: $10.3390 / \mathrm{d} 12070262$

Darwin C. 1862. On the various contrivances by which British and foreign orchids are fertilized by insects, and on the good effects of intercrossing. London: John Murray. 365 p.

Dixon K.W. 2009. Pollination and restoration. Science 325(5940): 571-573. DOI: 10.1126/science.1176295

Ercole E., Rodda M., Girlanda M., Perotto S. 2015. Establishment of a symbiotic in vitro system between a green meadow orchid and a Rhizoctonia-like fungus. Bioprotocol 5: e1482.

Euro+Med. 2006. Euro+Med PlantBase - the information resource for Euro-Mediterranean plant diversity. Available from http://ww2.bgbm.org/EuroPlusMed/

Fay M.F. 1994. In what situations is in vitro culture appropriate to plant conservations? Biodiversity and Conservation 3(2): 176-183. DOI: 10.1007/BF02291887

Girlanda M., Selosse M.A., Cafasso D., Brilli F., Delfine S., Fabbian R., Ghignone S., Pinelli P., Segreto R., Loreto F., Cozzolino S., Perotto S. 2006. Inefficient photosynthesis in the Mediterranean orchid Limodorum abortivum is mirrored by specific association to ectomycorrhizal Russulaceae. Molecular Ecology 15(2): 491-504. DOI: 10.1111/j.1365-294X.2005.02770.x

Han C.Y., Long C.L. 2010. Dormancy, germination and storage of Magnolia ingrata seeds. Seed Science and Technology 38(1): 252-256. DOI: 10.15258/ sst.2010.38.1.28

Johnson T., Kane M. 2012. Effects of temperature and light on germination and early seedling development of the pine pink orchid (Bletia purpurea). Plant Species Biology 27(2): 174-179. DOI: 10.1111/j.14421984.2011.00347.x

Kretzschmar H., Eccarius W., Dietrich H. 2007. The Orchid Genera Anacamptis, Orchis and Neotinea. Phylogeny, Taxonomy, Morphology, Biology, Distribution, Ecology and Hybridization. Bürgel: EchinoMedia Verlag. 544 p.

Leake J.R. 1994. The biology of myco-heterotrophic ('saprophytic') plants. New Phytologist 127(2): 171-216. DOI: 10.1111/j.1469-8137.1994.tb04272.x

Leitch I.J., Fay M.F. 2008. Plant genome horizons: Michael Bennett's contribution to genome research. Annals of Botany 101(6): 737-746. DOI: 10.1093/aob/mcn045

Magrini S., Barreca D., Zucconi L. 2019a. A rapid doublestaining technique to improve seed viability testing in terrestrial orchids. Plant Biosystems 153(6): 877-882. DOI: 10.1080/11263504.2019.1587541

Magrini S., De Vitis M., Torelli D., Santi L., Zucconi L. 2019b. Seed banking of terrestrial orchids: evaluation of seed quality in Anacamptis following 4-year dry storage. Plant Biology 21(3): 544-550. DOI: 10.1111/plb.12936

Malmgren S. 1996. Orchid propagation. Theory and Practice. In: North American Native Terrestrial Orchids. Propagation and Production Conference Proceedings. Germantown: C. Allen. P. 63-71.

Orsenigo S., Bacchetta G., Calevo J., Castello M., Cogoni D., Gennai M., Licht W., Montagnani C., Perrino E.V., Pinna S.M., Silletti G.N., Vela E., Viciani D., Vidali M., Wagensommer R.P., Zappa E., Fenu G. 2016. Global and Regional IUCN Red List Assessments: 1. Italian Botanist 1: 61-85. DOI: 10.3897/ italianbotanist. 1.8647 
Pierce S., Belotti J. 2011. The Conservation of Terrestrial Orchids: from the Alps to the Po Plain of Lombardy. Lombardy: POB and CFA. 89 p.

Poff K.E., Sharma J., Richards M. 2016. Cold-Moist Stratification Improves Germination in a Temperate Terrestrial Orchid. Castanea 81(4): 292-301. DOI: 10.2179/16-098

Rost T.L., Barbour M.G., Stocking C.R., Murphy T.M. 2006. Plant biology. Stamford, Connecticut: Thomson Corporation. $624 \mathrm{p}$.

Sharma J., Zettler L.W., Van Sambeek J.W., Ellersieck M.R., Starbuck C.J. 2003. Symbiotic seed germination and mycorrhizae of federally threatened Platanthera praeclara (Orchidaceae). American Midland Naturalist 149(1): 104-120. DOI: 10.1674/0003-0031(2003)149[0104:SSGAMO]2.0.CO;2

Stewart S.L., Kane M.E. 2006. Asymbiotic seed germination and in vitro seedling development of Habenaria macro- ceratitis (Orchidaceae), a rare Florida terrestrial orchid. Plant Cell, Tissue and Organ Culture 86(2): 147-158. DOI: $10.1007 /$ s11240-006-9098-y

Swarts N.D., Dixon K.W. 2009. Terrestrial orchid conservation in the age of extinction. Annals of Botany 104(3): 543-556. DOI: 10.1093/aob/mcp025

Swarts N.D., Dixon K.W. 2017. Conservation methods for terrestrial orchids. Plantation: J. Ross Publishing. $240 \mathrm{p}$.

Valletta A., Attorre F., Bruno F., Pasqua G. 2008. In vitro asymbiotic germination of Orchis mascula L. Plant Biosystems 142(3): 653-655. DOI: 10.1080/11263500802411205

Wraith J., Pickering C. 2018. Quantifying anthropogenic threats to orchids using the IUCN Red List. Ambio 47(3): 307-317. DOI: 10.1007/s13280-017-0964-0

\title{
МЕНЬШЕ - ЗНАЧИТ, БОЛЬШЕ: НИЗКОЗАТРАТНОЕ IN VITRO РАЗМНОЖЕНИЕ ИСЧЕЗАЮЩЕЙ ИТАЛЬЯНСКОЙ ОРХИДЕИ
}

\author{
Я. Калево ${ }^{1}$, М. Баццикалупо² \\ ${ }^{1}$ Туринский университет, Италия \\ ${ }^{2}$ Университет Генуи, Италия \\ *e-mail: jacopo.calevo@gmail.com
}

Орхидеи являются одними из наиболее широко распространенных растений, но также и наиболее уязвимыми при воздействии биотических и абиотических факторов. Их взаимодействия со специфическими симбиотическими грибами во время прорастания в естественной среде делает их размножение проблематичным для биологов, занимающихся их сохранением. В настоящем исследовании в рамках европейского проекта по сохранению растений LIFEorchids, был оптимизирован протокол по проращиванию семян исчезающего средиземноморского вида Orchis patens, а также было проведено сравнение эффекта контролируемой постоянной температуры в ростовых камерах с флуктуациями температуры, происходящей в естественных условиях. Жизнеспособность семян была также оценена с использованием техники двойного окрашивания. Минимальные, максимальные и средние значения суточной температуры фиксировались в течение шести месяцев, с июля по декабрь. Также доля прорастающих семян и стадии их развития были отмечены для обоих вариантов условий проращивания и каждый месяц. Даже с учетом того, что всхожесть семян была отмечена для обоих вариантов проращивания, эффект флуктуации температуры был показан, выраженный в увеличении доли прорастаниям семян около 10\% при постоянных условиях среды до 59\% в условиях флуктуации температуры. Последний результат был практически сопоставим с данными о жизнеспособности семян, показывающими сильное влияние флуктуаций температуры на нарушение покоя семян. Наши результаты являются подтверждением того, что температурные колебания играют более важную роль, чем средняя температура в прорастании семян, и предлагают избегать использования постоянной температуры для оптимизации протоколов прорастания для европейских видов орхидей.

Ключевые слова: асимбиотическое прорастание, сохранение ex situ, Orchidaceae, Orchis patens, температура, жизнеспособность 